\title{
POSTSOCIALISM OR WHEN 'HAVING' IS ANOTHER WAY OF 'BEING'. THE RECONFIGURING OF IDENTITY THROUGH LAND RESTITUTION AND THE NARRATIVES OF THE PAST
}

\author{
ELENA CHIOREAN 1
}

\begin{abstract}
In this paper I examine the consequences of the 1989 political overturn in Romania on the selfhood. To this purpose, I initiate a twofold analysis: the official discourse of both socio-political systems, socialism and liberalism, and the individual's quotidian discourse. The first one will enable a comparative view, over the 'bottom-up' constructed realities, and the second will account for the degree of pervasiveness and naturalization of ideological views and, in this way, of a "topdown" identity construction and its configurations. One of the most apprehensible provisions through which liberalism endeavoured to institutionalize its own way of setting out reality is land restitution. Thereafter, I will discuss the way re-appropriation was experienced and its various subjectivization trajectories, but also the wider frame of the postsocialist economic transformations: rethinking work, money, the state and the interrelations between them. This particular angle of sight will disclose the mechanisms through which liberalism has deconstructed the system of socialist meaning and representation, at the same time replacing it with a socio-political order which reconfigured these meanings.
\end{abstract}

Keywords: property, ideology, selfhood, socialism, liberalism

\section{Introduction}

But labor and land are no other than the human beings themselves of which every society consists and the natural surroundings in which it exists. To include them in the market mechanism means to subordinate the substance of society itself to the laws of the market.

(Polanyi, 2001:75)

Anyone interested in the present will be bound to glimpse at the past, and one of the most authentic ways to grasp it is social memory. Away from being a sheer subjectivization of one objective history, social memory turns out to be a

${ }^{1}$ MA in Applied Anthropology at the Babeș-Bolyai University, Cluj-Napoca and in Sociology and Social Anthropology at the Central European University, Budapest, e-mail: chiorean_ele_90@yahoo.com. 
vehicle for social identity, by means of which temporality can be inverted, thereby traversing a series of configurations of the self. Although always implicit - thus difficult to investigate - these configurations become nevertheless apprehensible when they undergo a process of restructuring, i.e. in times of social change.

The central aim of this paper is to understand the repercussions of the perspectival turn engendered by the 1989 political change in Romanian, thereby, the passing from state-socialism to liberalism, on the selfhoods that were subjected to this change. More precisely, I focus on the connection between political power and its discursive practice, and the process of social construction of reality by distinct ideologies in order to shed light on their consequences on identity construction. The fundamental premise of this paper is that, on the one side, the holders of central positions within the power structure define social reality in a particular manner and, on the other side, that this discursive production of reality will generate a more or less high level of naturalization of the respective definitions, and that these transformations will engender the reconfiguration of identity. As such, I will discuss of both socialism and liberalism in terms of ideologies that have the capacity to shape selfhood through a series of discursive strategies. Identity, on the other side, is conceptualized as the object of political struggle, hereby as a container of power relations, thus following the conceptual lines of Jenkins, Berger and Luckmann and Verdery.

Besides the fact that the land restitution (regulated by the Law 18/1991), initiated in 1991 and carried out painstakingly for a decade or more, was envisaged as a restoration of the situation before the communist takeover, thus implicitly assuming the legitimacy of the restated inequalities, the new liberal order used it in as a manoeuvre to reconstruct the previous conception over property relations and to restore private property as a value and a goal in itself.

This paper aims to contribute to the study of identity-transformations after the fall of state-socialism in Romania by investigating one of the most heavily idealized property relations, namely land ownership. The case of Romania is very interesting among the countries of the former Soviet-bloc, as Romania has, similarly only with Poland, a sizeable agricultural sector and rural population (almost 40\% of the population in the 1990s). However, unlike in Poland following Gomulka's reforms, in Romania the communist government did not rescale its kolkhoz policies and state-owned agricultural production units (Întreprinderi agricole de stat - IAS) and cooperatives for agricultural production (Cooperative agricole de productie - CAP) remained in place until 1990. Consequently, given the size of the agricultural sector and of the rural population, the fact that the newlyformed industrial working class had overwhelmingly rural origins, as well as the strongly idealized nature of land (as the land of the fatherland) and peasants' life at the countryside by nationalist discourses, it is right to assume that the process of land-restitution had effects beyond the mere restitution of former properties. That is, the reconstruction and re-legitimization of the pre-socialist individual. 
In order to understand the identity transformations produced by the fall of communism and the role of land restitution, I carried out a comparative microanalysis of several distinct cases of land restitution in a village located in the historical region of Transylvania, Nădășelu. The case of Nădășelu is illustrative for the purposes of this study, firstly as collectivization had been performed here in the last wave, as late as the early 1960s, so memories are still vivid. Secondly, due to its spatial proximity to Cluj-Napoca, a large part of its younger labour force has been absorbed by the expanding city and its industrial enterprises under state socialism. However, most of these new workers were either commuting, or regularly returning to the village, and have contributed to the local agricultural work during their free time. In these conditions, land restitution engendered a variety of responses, from a reverted migration wave (workers who relocated in the village), to an urban-rural wave of commuters, engaged in agricultural labour not as a complementary activity, but as a second main workplace. At the same time, Nădășelu provides a distinct postsocialist story - at least in the first few years after the fall of communism - given that former local elites initiated the creation of a farmers' association which took over most of the properties which have been part of the former CAP, and which utilized the agricultural machinery of the former station for the mechanization of agriculture (SMA).

I have conducted semi-structured in-depth interviews with former CAP members whose land entered the collective, as well as with CAP workers with no or little land at the time, and also with commuting industrial workers. Altogether, in April 2012 I have interviewed eleven villagers (eight women and three men, with ages between 61 and 80 years old at the time of the interviews), of which six have participated in CAP work (most of them as members of the cooperative), while the other five have only done so occasionally or have not.

\section{Building postsocialist identity through possession: land restitution}

Among other major transformations, land restitution was instrumental for the naturalization of the liberal discourse - with its claim for the hegemonic definitions of individual's social identity and legitimate social relations - and in setting an ensemble of significations and representations, that engendered a partial restructuring of these identities. Lampland endorses this view when she asserts that decollectivization has been a process that, more than a simple restructuring of economic institutions, entailed a more general transformation of social relations and social representations (2002:32). Or, in Verdery's terms:

The story of property restitution is a story of forming (or failing to form) potentially new kinds of persons, along with new social identities based in property and possessing. This story is part of the larger drama of transforming Romania's class structure, economy, and system of state power (Verdery, 1996:135). 
This is precisely the core assumption of the following discussion, one that I will endeavour to explicate throughout this paper. However, the eventuality of these profound identity reconfigurations is partially undermined - if we were to line up with Humphrey's argument - by the general incapacity of a socio-political system to abruptly and integrally substitute the previous social practices and institutions, as well as - paradoxically, yet understandably - by the pervasiveness of socialism, whose echo in the everyday life and social narratives are undeniable (Humphrey, 2002:12).

One of the central concepts that I instrument in analysing the emergent transformations after 1989 is that of social identity, as the object of the modalities and strategies of instituting a distinct social order, hereby of redefining reality. Social identity is therefore regarded here as a social product that is institutionalized by distinct ideologies, or, in other words, as the objectivation of distinct realities. Jenkins (2008) argues that collective identity and individual identity ought not to be treated separately, since both are based on interaction and are built in the same way (2008:37-8). The selfhood, as an individual identity is constructed through a constant interaction with others, thereby being a "dialectical synthesis of internal and external definitions" (2008:41), i.e., of self(-) and hetero(-) social definition of the individual. In Jenkins' terms, individual identity is the one that is altered once liberalism takes socialism's place, both by institutionalizing a different perspective on the world (which provides a new set of conditions for social interaction, by authorizing other relations, and, at the same time, by the reconstruction of social categories in accordance to different criteria), and by relocating individuals within the social space, in terms of self-representation. Following his argumentation, the distinction between group (as a community that represents itself in these terms) and category (a hetero-assignation of the similar character of its members) is relevant in understanding the manner wherein the formal discourse operates and its naturalization. Starting from Marx's distinction between class in itself and class for itself, Jenkins asserts that transposing a category into a group is a political process which implies the institutional definitions of reality. Identification is, as such, one of the objectives of political struggle, and power relations are intrinsic to identity (Jenkins, 2008: 44-5). This is the driving force behind the reconfiguration of identity that takes place after 1989 - if socialism and liberalism are understood as fundamentally distinct manners of ordering reality - which entails the reconceptualization of legitimacy. Or, as Berger and Luckmann (1991) argue:

Since the identity that is known or knowable by the gods, by psychiatry, or by the party is at the same time the identity that is assigned the status of paramount reality, legitimation again integrates all conceivable transformations of identity with the identity whose reality is grounded in everyday life in society (Berger and Luckmann, 1991:118). 
Social change implies, as such, objectivating a subjective reality and imposing a series of significations progressively distanced from the previous symbolic system, which produces a complex of restructured identities, a process that is facilitated by the flexibility and multidimensionality of identity - as Corduneanu says, identities „are not just pre-given, stable, unmovable concepts. On the contrary, they might be at the core of different processes of negotiation" (Corduneanu, 2002:5). In this way, those who hold the power are also those who have the power to shape the process of identification (Berger and Luckmann, 1991: 137). As such, although in socialism the distinction between private and public identities was rather sharp, certain public representations have been pervasive. However, this pervasiveness has been undermined by simultaneous experiences and conceptions that unfolded outside of the public life (Kideckel, 1993).

The second fundamental concept that I rely on in analysing postsocialist transformations is that of property. According to Kornai (1992), private property is founded on the principle of exclusivity, such that it regards, on the one side, a relation between the individual and an object and, on the other side, a relation between individuals, which is founded on the norms and the rights which emerge from possession. The first of these rights is the right to benefit from the income that property engenders. The second, the right to freely utilize this property, that is, to sell, to rent, to donate etc., even though they might not overlap. The last one is that of deciding on the manner wherein it will be used and the possibility of transferring administrative rights. These three types of rights can be associated in certain ways, which is what Kornai calls property forms. Kornai argues that even though theoretically the number of such combinations is infinite, particular societies institute specific property forms. The dominant property form in socialism, for instance, is state property, which is devoid of alienation rights, places decisional rights in the hands of the bureaucratic apparatus and appears as "depersonalized", since it does not have an identifiable human owner. The second property form in socialism is collective property, institutionalized as a cooperative, which formally entails the collective ownership of the means of production by voluntarily associated individuals. Empirically, however, coercion was utilized to form the communist collectives, and members' rights were insignificant. Therefore, in this case, collective property becomes state property.

Marcuse's comparative analysis of property rights (1996) as they have been defined in the Soviet Union (in its maturity stage, since they have been significantly changed over time) and the capitalist West adds to Kornai's analysis, through the differentiation of the different specific configurations of the system of rights intrinsic to property in the two regimes, seeing that one of the central discrepancies between them regards the legitimacy of instrumenting property with the aim of profit, which is absent in socialism. At the same time, 
another distinctive factor regards the agencies that sanction these rights: in capitalism, the judiciary system; in socialism, executive and legislative forces. This distinction is explained as a product of the unclear delineation between power institutions in socialism, such that the judiciary system is not a defendant of individual rights against the state. On the contrary, these rights are regarded as components of a mechanism that ought to work for the common good (Marcuse, 1996:136-7). Kornai suggests, further on, that private property and market economy are essential to a democratic system, which becomes untenable if they are absent (1992:36).

Kornai's view on property as a system of rights based on exclusion is opposed by that of MacPherson, who argues that the meaning of property is neither universal nor fixed, but it is transformed according to the aims that property institutions are directed to, which, in turn, are configured by the dominant classes. As such, property is a "political relation" between individuals, ideologically authorised, which differentiates it from material possession (1978:1-4). Equating property with the rights attached to it is actually a product of $16^{\text {th }}$ century market capitalism, and parallels the marketization of land and other possessions, which corresponds to a commodification of rights. In the $20^{\text {th }}$ century, the meanings of property have been refocused on the rights attached to it. However, the latter did not regard the quality of owner, but the potential of the object to generate benefits, its profitability (MacPherson, 1978:7-11). More than that, in a remarkable critical endeavour, Humphrey and Verdery (2004) plead for the dismantlement of the ideology of property - closely connected to the legitimization of liberal democracy by questioning all concepts that it operates with, including that of right (which entails a universal prioritization and a simultaneous exclusion) or those of relation, individual, or object, all with a West European (colonizing) cultural bearing, wherein the individual is defined as a unitary entity, with a fixed identity, and a clear delineation between it and the material world (Humphrey and Verdery, 2004: 5-7). Following the principle embraced by the two authors, I agree that:

...property can be regarded as a set of relations, as a powerful political symbol, as a process of appropriation or, perhaps more important, as a historically contingent western "indigenous category", with strong effects in the world (Humphrey and Verdery, 2004: 20).

A similar take is that of Hann, who asserts that privatization does not function as a provision that could counteract the deficiencies created by socialist economic policies or as one that appertains to an attempt to restore moral justice, but rather as an enforcement of the postsocialist hegemonic ideology (2002:3).

Turning back to Kornai, some amendments should be drawn to his analysis of the relation between property and the political system. Firstly, capitalism is seen by Kornai as the natural order of society, as opposed to socialism, an artificial system 
whose driving force is coercion (Kornai, 2000: 31-2). By contrast, I line up with an approach that sees both regimes as ideologies. From a constructivist stance, both are distinct modalities to create social reality and to impose a specific definition of reality, thereby normatively dividing between the natural, thus the legitimate, and that against the nature, i.e. the illegitimate. Consequently, Kornai's assertion that private property is natural constitutes a political statement embedded in a liberal worldview. Therefore I refer to private property not as a natural phenomenon, but as a typical artefact of liberalism.

\section{The liberal discourse. The naturalization of possession and the reification of genealogy}

The story of one of the families I have talked to about what happened after 1989 offers a quite revealing outlook on the aftermath of the Revolution. In 1991 family Q. is given property rights over almost ten hectares of land, located near Cluj-Napoca. The husband (I., 63 years old ${ }^{2}$ ) had been working as an electrician in a machine tool plant in Cluj (until 1993), and the wife (B., 56 years old) at Agrocoop, a state-owned company commercializing fruits and vegetables during socialism. B. went on maternity leave while Agrocoop was still in place, but after her maternity leave was over, she did not return to her job, but took on the double role of a housewife and agricultural family worker. Once the family land was restored to the family, I. decided to take a loan in order to purchase agricultural machinery, as he had planned to start cultivating the newly acquired land. However, a few years later the interest rises to almost $100 \%$, so that he was forced to sell their apartment in Cluj in order to pay the loan. Consequently, I., B. and their three children moved in with I.'s mother, in Nădășelu.

The mechanization of agriculture during socialism induced a particular view on the cost-benefit rapport and small-scale production: a particular understanding of the labour force relative to technical means, where surplus value can only be obtained by calibrating the two, through the rationalization of production. Yet, the new emphasis on the individual/the private rather than on the state/the collective determines a direct connection between the idea of profitability - closely connected to the technologization of agriculture - and the entrepreneurial capacity of the individual. As Verdery argues, in socialism efficiency is not linked to profit, but to the full utilization of resources and means of production, which separates the socialist and the liberal rationalities (1996:47). Once land property was restored, regardless of the absence of technical means of production and of the negative cost-benefit rapport (simply put, the value of the

2 The age of my informants is that at the time of the interviews, April 2012. 
investment, including paid or unpaid labour, is higher than that of the product), a newly (re)created affective relation between the individual and the land, build on the romanticized vision of peasantry and the countryside as containers of the genuine nation, leads to a sense of moral onus in cultivating the land. This is not only the case of the family Q., but also of several other informants. V., for instance, whose family owned a rather large land tract (fourteen hectares) told me:

I went to Berind and I have there a piece of land from my mother's side, I received my mother's land, 66 years old. Hear me out, when I saw myself stepping on it, I felt such joy that I didn't know what to do: to shout, to laugh, to welter in it, that's how much I loved it! Wonderful! I can still see it! (V., 78 years old).

Returning to family $\mathrm{Q}$., in order to conciliate the need to cultivate the land and the need for subsistence, a micro-division of labour was set within the family: B. turned to the land, while I. turned to entrepreneurship. A simultaneity of a temporality that was conceptualized in distinct ways: turning to the future, on the one hand, and the attempt to recreate a lost connection with the past, on the other. B. told me: „you felt that justice has been made for your forefathers, who fought for that land" (B, 56 year old woman, agricultural family worker).

The restitution of land - as a strategy to reinstate the pre-communist order, as a modality to create the postsocialist identity and as an anti-communist provision (Verdery, 2000) - brought about a new approach to property and the proprietor-property relation. Not only that the former needs to be capitalized on, but its restitution was perceived as an ancestorial recoil. As a consequence, the owner is morally obliged to safe her property even at high costs:

[...] and then he sold the apartment, to pay the loan, 'cause my mother-in-law would have died of a broken heart if he sold her house; and the land was here [in the village], 'cause the land was the reason why he took the loan (B., 56 old year old woman, explaining why her family chose to sell their apartment in the city instead of the countryside house, located near their land property).

The reinstatement of landed property, on the one side, was a symbolic break from a social order centred on the worker, the industry, hereby the urban, a return to the valorization of agriculture and of the "rural culture", such that decollectivization had direct consequences on the reconfiguration of the postsocialist selfhood. On the other side, it was signified as an act of justice, aimed to "return" a series of rights that individuals had been deprived of. Setting the emphasis on right restoration, coupled with obscuring the obligations that the new owners will have, is one of the dimensions of land restoration that Verdery criticizes, as part of a transfer of rights from the state to private actors (2004:140-1). In regards to the first understanding of land restitution, the land and its ownership was represented as an extension of the self or the rehabilitation of a lost part of the self. As part of a liberal worldview, it attempted to re-naturalize individual material possession. 
In this way, a regeneration of traditional (as opposed to socialist) values unfolds, as an act of axiological disengagement with a political order deemed deleterious and as an endeavour of societal reformation. Moreover, as a return to the past by planning an utterly different future, a normative approach to a world ${ }^{3}$ which is thought to be built negatively, since it aimed at reconstructing the individual and her ontological identity in an artificial manner. Communism is represented, as such, as the overturn of a natural order, as a counter-narrative, due to its attempt to suppress private property and even individuality (through homogenization) and the attempt to build an "artificial" equality. Or, put otherwise, the attempted replacement of equity with equality, which threatens the ontic status of the individual. As such, socialism and liberalism are discursively constructed as being in total opposition, as antagonistic categories.

\section{The chimera of abundance: minimal state, privatization and reorganized labour}

One of the central postsocialist transformations in regards to the reconstruction of identity is that of the morphology of categorization. Kideckel argues that "[p]ostsocialism elides the significance of class not only by defining new relationships between state, society, and the individual, but also by creating those relationships in new ways" (2008:10). Liberalism relies on the idea of minimal state intervention and competition - and thus individual success as given by entrepreneurial qualities in all social spheres. The emphasis is set, as such, on the individual, who although constitutes a unitary ontic category, shares the same rights and liabilities as the others, consequently social hierarchy should be seen as quasi-natural, arising from inequalities of psycho-social qualities between different individuals. The state, in this way, is an organism external to society, which is bound to monitor the preservation of these free relations between people. Seeing this conceptual framework, it will not come as a surprise that private property is privileged, since it is seen as the premise of all social-economic relations. To the extent that the private is identifiable with the individual, and the status of singularity is superior to that of plurality (i.e., community), a delineation should be done between that which appertains to the collective and that which is attached to the individual.

All these created an illusion of fairness and meritocracy, which added to the representation of capitalism as superior to socialism and to the appearance of an unlimited possibility for individuals to increase their economic capital, with

\footnotetext{
${ }^{3}$ I utilize this concept in Verdery's acception, as the union between a 'view on the world' and intentionality, as an actional impulse, and the behaviors that mesh with them or derive from them (Verdery, 2000:34).
} 
the sine qua non condition of entrepreneurship. The individual is given the freedom to organize her work and adopt the cost-benefit rationality, but the results of this organization of labour are unpredictable. Responsibility is transferred from the state to the individual and from the public to the private.

\section{Postsocialist agricultural associations: making possession profitable and the monetization of the land}

Returning to the restitution of landed property, the village I have done fieldwork in provides an interesting instance of a postsocialist form of labour with socialist roots, which aimed at preserving the organization of the CAP, but made use of capitalist forms of rent, which was however dismantled after a short while. The owners were given the possibility of registering a share of their land, or their entire property, in the association, in exchange for a share of the resulting produce. The association was created with the support of the former Station for the Mechanization of Agriculture (SMA) in the nearby village, which provided the agricultural machinery that the cultivation of large areas of land required - and which the new owners did not own. It is no coincidence that the former local elites have been the founders of the association, since they were the ones who controlled the former SMA, thus those who were in charge of its property. However, the association often appealed to the help of the owners in farm work an element of resemblance with the CAP. As such, local elites seem to have endeavoured to preserve the illusion of continuity, of security, in this sense, but eliminating the previous system's deficiencies: the new owners did not need to make any effort in cultivating the land (in principle), they benefited from a large share of the production, while they were given the sense of possession, with the adjunct decisional rights in regards to the usage of the land. Concerning the strategies that local elites made use of in order to maintain and reinforce their positions, Lampland (2002) provides a pertinent source for explanation. Following Bourdieu's (1986) view on social capital, she examines the construction of collective farms in postsocialist Hungary and the manner wherein the former administrators of the farms instrumented the social relations they had formed during socialism, which generated farm viability by maintaining a high area of land within the farms. In the case of the association in Nădășelu, the downgrading of the administrator's relation with the new owners brought about, to a certain extent, the dismantling of the farm.

Entrepreneurship, another dimension of the postsocialist identity, was deemed necessary in agriculture as in other domains, in the sense of managing resources - including property - in a rational way with the aim of profit, a phenomenon that, as Verdery argues, is paramount to the process of privatization, as a "panacea for all social ills" (Stanilov, 2007:272), in its entirety, which "created 
new types of persons, who would be economically responsible individuals bearing not just rights but risks and debts" (Verdery, 2004:140). This managerial skill manifests itself here through the distinctive understanding of the relation between property, amount of human labour spent, technology, and the equitable assignation of products, according to the quality of owner, on the one side - which contains in itself the right over the product - and, on the other side, the quality of worker, by the energy that is spent in the labour process, which affords the right to a share the products as well. The conceptualization that emerged once liberalism took hold with regards to this relation resides in the possibility to separate labour from ownership. If technical means of production were absent, surplus value could be obtained only by dividing the two. The idea of profitability-efficiency (rentabilitate), and its intrinsic connection with technology emerge once more, as a central conception of socialism. Efficiency entails, as I mentioned earlier, a positive rapport between investment and output, which is related to a rationalist understanding of economy. This rationalization is noted by Goina as well, who asserts that "the construction of the cooperative produced a novel perception over time, a rational and normed one, different from that of the peasant, which is a homogenous and a continuous one" (2005: 382-3). Property becomes efficient (rentabilă), as such, only in so far as, in the conditions of the absence of technical means, land is exploited by someone who owns them, but who does not possess it. The bankruptcy of the association was explained precisely as an effect of the lack of profitability, given by the macro-economic conditions: inflation, higher fuel prices and wages, which made it so that the cost of labour exceeded the produce:

The association worked for some years, but they had no profit, 'cause in the meantime the prices of diesel oil, nitre, herbicide kept rising, the wages kept rising - of the tractor drivers, 'cause they had to pay them. It didn't work out and they gave up. They are the ones who gave up, not us. Later on, people were very displeased, 'cause they were the ones who had to work the land now. And if you have no machinery, it's not efficient (B., 56 years old, woman agricultural family worker).

The idea of association is recurrent in all of my interviews, under different forms, as a viable solution for obtaining a profit on the land. As I mentioned above, the desideratum of raising efficiency in agriculture is part of a particular manner to conceive the relation between labour force, means of (agricultural) production and possession, as it was construed in socialism, an economic rationalization that within liberalism fuses with entrepreneurial principles. The liberal touch is given here by the finality that any such labour must have, that is, profit:

If they had made an association - but who knows for how long it would have worked - then you had a half hectare garden that would have been enough. And you rented the rest and then you got something in exchange. You see, nobody came here to give you anything. They didn't rent the land here (N., 68 years old, farmer). 
Therefore, subsistence agriculture or the affective dimension in the relation with the land become irrational, and the connection with the land will be assessed according to liberal principles. In the pre-communist times, this connection was generated by a direct conditioning of one's social status by the land area owned, which amounts to construing a strong interconnection between the owner and land, to a point where the two entities merge (Kideckel, 1993: 48-53). After the fall of communism, however, a process of mediation through abstractization - and, at the same time, standardization - of the value of the land unfolds, monetizing it. Land becomes a commodity, whose value is quantified according to its capacity to enter the market, and ownership is merged with entrepreneurship, which entails here, on the one side, transactional skills and, on the other side, shifting the reference frame from the communal to the societal, i.e., the land is no longer a direct indicator of social status in a relatively small community, but only through its transference in the abstract sphere of money. Hereby, the individual positions herself in a wider system of social statuses. As a consequence, an impersonal economic element that synthesises the complex relation between the owner and her land is interposed between the two. The affective-emotional and culturally-symbolic components are transposed in a clearly circumscribed, abstract unity, the product of a social convention which creates a commodity whereby all other commodities are assessed and which provides a conceptual instrument which embodies their value. This process however is not abrupt, but progressive, unfolding as the liberal discourse is naturalized and becomes more and more intrusive. As such, a shift has occurred, from the manner in which the restitution of the land had been reconceptualised right after 1989, to the liberal view on property:

People were happy, but they can't do anything with the land [...]. There's nobody to cultivate it, and if you want to sell it, there's nobody to buy it (N., 68 years old, farmer).

Notwithstanding, social reality is far from being univocal. The above reasoning is only partially valid and only for some cases. The other side of the story appears in those cases where the restitution of the land was a purely formal event, seeing that the sense of possession was preserved during socialism as part of an informal counter-discourse and merely the official ownership rights were lost back then. The explanation of this fact is twofold. On the one side, there is the idea of genealogical continuity; on the other, the relation between labour and possession. In the first case, sensing the nationalization of the land as something final, unchangeable, would have produced a symbolic genealogical cleavage, seeing that land had a significance that transcended its economic value. The second case entails a conceptualization of property rights as partially generated by the energy that is spent in exploiting the land - partially, since possessorship is socially 
authorised by the lineage system, despite changes in the legal system over property. For the members of this category, labour contains the right to appropriate its product, consequently taking some products from the CAP "illegally" was not perceived as morally wrong. If in the case of the postsocialist association in Nădășelu the division between labour and possession was voluntary - and connected to a certain understanding of rational property management - in CAP it was seen as a forced one, and not felt as authentic: "So you were cultivating your own land, and they were giving you something extra [...] for your labour" (N., 68 years old, farmer).

Therefore, it is not without grounds to distinguish between a series of realities, according to the degree of pervasiveness and naturalization of the ideological discourse. The liberal view partially superposes with the social order that is deemed just by the former owners socialised before socialism and transferred to the next generations as cultural heritage, through a process of representational succession which contributes to the naturalization of private property.

\section{Social memory and the construction of past narratives: intersubjectivity and comparative assessments of "communism" and "democracy"}

The past, as it is mapped by historians, seldom coincides with the past which is imprinted in the collective memory or, taking one more step towards subjectivity, with the individual memory and the vernacular discourse over memory, as different from the dominant discourse of political elites. As Corduneanu argues, in regards to the interaction between the subject and the institution that strives to impose an identity, one of the modalities whereby the latter can be constructed is rewriting history, which creates an "official memory" that "tried to silence any other alternative forms of social memory" (2002: 6). All these varieties are primal to understanding social reality, pre-eminently to explaining the nature of certain representational systems at a given time.

Along with individual interviews, I was given the chance to participate in a micro-group discussion about socialism, the Revolution and liberalism, which opened the possibility to juxtapose the unfolding of this conversation with those created by the context of one-on-one interaction. The former case implicated three women relating their lives under state-socialism, without much verbal interference from my side (I only displayed my interest for the conversation to go on). However, my presence - as an individual who was socialized in liberalism - shaped a complex of discursive elusions, whose purpose was setting out a shared register, a common ground. It would not be unlikely for this to be another determinative, which has influenced to some extent the other aspects of the narratives, as an 
adaptive strategy to the particular situation created by the interview. Although I take this into consideration I believe, however, that talking to people I knew very well before the interview, the provoked derogations do not have such powerful outcomes as to completely obliterate the validity of these interviews. Nevertheless, whether I made explicit what was a matter-of-course - the fact that I had not been living under socialism, so I do not possess any experience-based knowledge - or whether my interlocutors did so, during the most successful discussions a virtual negotiation of temporality occurred i.e. an extension of each selfhood, which resulted in the prompt establishment of a shared memorial arsenal, through intersubjectivity (in the sense of a reciprocal empathetic approach, and the employment of an implicit social register, without appealing to explanatory linguistic constructions, which would facilitate understanding; this alludes, actually, to empathic comprehension). In other cases, the distinct memorial background was marked out, a setting which reverberated over the discourse's construction and which ended in resorting to a series of additional explanations (and, in turn, this brought about particular hesitations, caused by the assumption that it will turn out to be utmost troublesome to find a common ground). Contrariwise, in the case of the discussion with three women, my interferences were minimal once I delivered the subject, a stage followed by a process of calibration of narratives and memory negotiation between them. Narrating their shared experiences, certain discrepancy of their memories unfolded, and, in addition, divergent evaluation of socialism, a theme I will address later. Thus, while being enlisted in a collective memory recovery, they engaged in a process of configuration of past narratives, in an effort to trace some points of convergence, with the scope of designing an outline for a conjoint discourse of social memory, which would prevent supplying contrastive information and thereby an equivocal reception of the message, thus placing themselves in the posture of reliable sources of social knowledge. Hence, from the dialogue's onset up until its end there was an upspringing of an almost unitary, incorporated memorial 'entity'; the three women cease to contradict one another and begin to round off each other's sentences, which substantiates the strategy of memory's social construction and the fusing tentative of the narratives of the past.

Arguments surrounding the dilemma "socialism versus liberal marketeconomy, which is better?" abounded in these conversations. The most salient aspect in favour of socialism concerns the workplaces and relatively decent salaries provided by the state. The withdrawal of the state under the new liberal regime and the enfranchisement of the economic sphere from its tutelage was perceived as a loss. In this way, most of my interviewees were supportive of the tenet of the welfare state. In this view, the state and society overlap almost integrally (the state can be understood as a supra-network, which annexes itself to society, and shapes its structure; a meta-society), and the latter encloses a regulatory apparatus of the everyday life. The state is, at the same time, a source of meaning for social reality and for the legitimate manners of interrelating. The 
individuals are no longer entities whose ontological status would grant them the generation of a complex of a priori distinction principles, but their ontological morphology is correspondent, even coessential. Whatever distorts this identity unity can only be linked to a set of corporeal, tangible, external appendages whereby the social self will be objectified (precisely because these material extensions will determine social relations, as well as the individuals' selfdefinition, through their subjectivation). The state is vested with the mission to deplete the dynamic system of social relations, to "streamline" it, by suppressing the material extension of identity. While in the liberal view the state is - more than an external arbitrator which ensures the observance of the individual rights - in its turn a free and competitive agent, in this case it is a polymorphic resort: on the one side, it organises social life, in its entirety, by instituting an order in which the individual concedes a fraction of her peculiarity for the category to which she is attached and, on the other side, it is a collective actor in social life (the state is, actually, the sole owner and the decision maker, but also the human collective within the national borders - this is why I defined it earlier as a meta-society), thus having a dual nature.

Within the socialist social order labour is central. First, labour ensures the free contribution of each member of society to the common wealth. Second, work (and communist labour) is understood as the fundamental human activity, around which the rest of the social life is interlaced. Third, labour is the source of social prestige and access to state redistribution. Finally, labour counterbalances the protection that the individual receives from the state conceived not solely as security, but also as ensuring the living conditions that would generate predictability - embodying at the same time a liability towards the state (and therefore to the community and by this to itself). Hence, labour is not apprehended as a strategy of accumulation and it carries an innate restrictive mechanism originated in the process of social uniformization and the lack of private property. The case of the CAP members is extremely revealing in this respect: those who were registered in the CAP were given 30\% from the total of production, while $70 \%$ belonged to the state. Certainly, these data correspond to formal proportions. Given that agricultural production was often over-reported, and the share of the state was computed from the fictitious (and not the actual) production, the real share of CAP members was often minimal. Conversely, they found alternative ways whereby they acquired additional produce. Thus, as opposed to liberalism, where private property dictates social relations, socialism is seen to be founded on labour:

Still, it seems to me that there weren't so many needy people back then, as you can see now, 'cause back then one was forced to work, willy-nilly. And the salary was enough too, enough to build a house, to buy some furniture, to... and our children had everything, so... the salary was big enough (M., 61 years old, former telephonist). 
The money was scarce, but one could pull through. Now, even if there is more money, you can't. And nobody starved. There are even more needy people now than there were back then. Back then you did what you could and still... those who couldn't handle it were very rare (N., 68 years old, former employee of the local cooperative).

You know what?! It was way better back then! You hadn't so many as you can have now. Everybody had a job, if they had a higher salary, not so much... [a high salary was uncommon]. Almost everybody had the same (L., 65 years old, former employee of the local cooperative).

But back then, in Ceaușescu's time, you had what you needed, everything! (A., 78 years old, former employee of the local cooperative).

Retrospection generates a negative account of liberalism, even by those who profess themselves as the advocates of the liberal-democratic view, assessment which is based on the decline of production and the rise in consumption, but also on the deprecation of privatization. The latter is seen as a dynamic phenomenon directed against the nation's best interests, the postsocialist elites being the ones responsible for its initiation:

We were happy that he [Ceaușescu] won't be [in charge] anymore. But then we saw Iliescu, who positioned himself in power. 'oh, it will get better now!'; but you see, it wasn't any bit better. Was it? What was done in the past 22 years? They have all stolen, isn't it? [They stole] Everything they could, they built villas, they made fortunes, they bought lands (V1., 65 years old, former employee of the local cooperative).

The manner in which this process is conceived accounts for a complex of socialist reminiscences of the modes of representation of the state: privatization is regarded as a regression of the nation-state's hegemony, which can only be influential by possessing the whole of elements framed within its borders (this includes not only the territory but also the safeguarding of control over the economic sphere). Here is the statement of one of the people I talked to concerning this matter (the context for this assertion is a discussion about the privatization of the 'Beer Factory' [the brewery] in Cluj, where he had been employed for fifteen years, a fact which provoked him a great wrath):

Slowly, slowly, one fine day we'll dawn as a part of Hungary. It's not ok to sell the country this way. Especially its agriculture... (V., 70 years old, former employee of the local brewery).

The reprobation of the coercion system that operated during socialism, although present in my interviews, weighted less in the discussion. 


\section{Conclusions}

The fall of the communist regime and the novel blossoming of liberalism reverberates over social identity, which is reconfigured through the redefinition of reality and through the institutionalization of a distinct view over it. The configuration of power relations is essential for this process, yet the analysis of power cannot be reduced to the investigation of political elites and their attempts to impose a reclassification of social positions and a new social order. In this paper, I explored how the ideological turn occurred or failed to occur among the large segment of former agricultural or industrial workers who regained their land properties, collectivized or nationalized under state socialism. Their "resocialization" 4 as land-owners and farmers involved not only a restored social role, but a different world. This perspectival shift has been felt as the dislocation of previous identities, even though the socialist discourse was not fully internalized. The construction of an entrepreneurial society engendered the progressive transformation of the manner wherein the individual is conceptualized and the naturalization of the liberal discourse. The entrepreneurial self is something to be learned even by those who maintained their sense of possession over "their" land under state socialism, regardless of its incorporation in the cooperatives or state-owned farms. Simultaneously, the quotidian discourse unravels socialist reminisces, accounting for the relative rigidness of identity and, in this way, for the production of a series of distortions within the social world as it is shaped by liberalism.

The personal narratives of the past and the social memory that they engendered disclosed all these mechanisms in plenty of details. The manner where in these subjective memories are constructed unravels identity reconfigurations, through its juxtaposition with, or distancing from the ideological discourse, the construction and reconstruction of history in different regimes.

\section{REFERENCES}

Berger, P.L.. and Luckmann, Th. (1991). The Social Construction of Reality: A Treatise in the Sociology of Knowledge. London: Penguin. (First published, 1966).

Bourdieu, P. (1986) The forms of capital. In J. Richardson (Ed.): Handbook of Theory and Research for the Sociology of Education, New York, Greenwood, pp. 241-258.

\footnotetext{
${ }^{4}$ Although generally understood as a politically neutral concept, my understanding of the concept of socialization is far from such a neutral stance. The former understanding is usually generated by a conceptual division between the "social" and the "political", such that the latter could not be sufficiently pervasive as to impose a certain worldview through a similar learning process. However, I consider that society is by its very nature political and that different ideologies have the capacity to produce such transformations in worldviews, seeing that each society is an ideology.
} 
Corduneanu, I. V. (2002). Cultural Identities and the Research of Recent Romanian Past. Southeastern Europe/L'Europe du Sud-Est, 29:1-16.

Goina, C. (2005). "Ce poţi face azi nu lăsa pe mâine": cazul colhozului-model "Viaţă Nouă", Sântana [„Don't do tomorrow what you can do today”: the Case of the Prototipe Kolkhoz „New Life”, Sântana]. In Dobrincu, D. and Iordachi, C. (eds.): Țărănimea și puterea. Procesul de colectivizare a agriculturii în România (1949-1962) [Peasantry and Power. The Collectivization of Agriculture in Romania (1949-1962)]. Iaşi: Polirom, pp. 368- 392.

Hann, C. M., Humphrey, C., Verdery, K. (2002). Introduction: Postsocialism as a Topic of Anthropological Investigation. In Hann, C.M. (ed.): Postsocialism: Ideals, Ideologies and Practices in Eurasia. London: Routledge, pp. 1-28.

Humphrey, C. and Verdery, K. (2004). Introduction: Raising Questions about Property. In Humphrey, C. and Verdery, K. (eds.): Property in Question: Value Transformation in the Global Economy. Oxford: Berg, pp. 1-25.

Jenkins, R. (2008). Social Identity. New York: Routledge. (First published, 1996).

Kideckel, D. A. (1993). The Solitude of Collectivism. Ithaca, New York: Cornell University Press. (2008). Getting By in Postsocialist Romania: Labor, the Body, and Working-Class Culture. Bloomington and Indianapolis: Indiana University Press.

Kornai, J. (1992). The Socialist System: The Political Economy of Communism. New York: Oxford University Press, pp. 62-91.

(2000). What the Change of System from Socialism to Capitalism Does and Does Not Mean. Journal of Economic Perspectives, 14(1):27-42.

Lampland, M. (2002). The Advantages of Being Collectivized: Cooperative Farm Managers in the Postsocialist Economy. In Hann, C.M. (ed.): Postsocialism: Ideals, Ideologies and Practices in Eurasia. London: Routledge, pp. 31-55.

MacPherson, C.B. (1978). The Meaning of Property. In MacPherson, C.B. (ed.): Property: Mainstream and Critical Positions. Toronto: University of Toronto Press, pp. 1-13.

Marcuse, P. (1996). Privatization and Its Discontents: Property Rights in Land and Housing in the Transition in Eastern Europe. In Andrusz, G., Harloe, M., Szelenyi, I. (eds.): Cities after Socialism: Urban and Regional Change and Conflict in Postsocialist Societies (Studies in Urban and Social Change). Oxford: Blackwell Publishers Ltd., pp. 119-191.

Polanyi, K. (2001 [1944]). The Great Transformation: The Political and Economic Origins of Our Time. Boston: Beacon Press.

Stanilov, K. (2007). Democracy, Markets, and Public Space in the Transitional Societies of Central and Eastern Europe. In Stanilov, K. (ed.): The Postsocialist City: Urban Form and Space Transformations in Central and Eastern Europe after Socialism. Dordrecht: Springer, pp. 269-283.

Verdery, K. (1996). What Was Socialism and What Comes Next?. New Jersey: Princeton University Press.

(2000). The Political Lives of Dead Bodies: Reburial and Postsocialist Change. New York: Columbia University Press.

(2004). The Obligations of Ownership: Restoring Rights to Land in Postsocialist Transylvania. In Humphrey, C. and Verdery, K. (eds.): Property in Question: Value Transformation in the Global Economy. Oxford: Berg, pp. 139-159. 